\title{
HUBUNGAN PENGETAHUAN IBU POST PARTUM TENTANG MANFAAT KOLOSTRUM DENGAN PEMBERIAN KOLOSTRUM PADA BAYI BARU LAHIR DI BPS. AIDA HARTATIK Amd, Keb DS.DLANGGU Kec. DEKET LAMONGAN 2015
}

\author{
Mimatun Nasihah* \\ Lilis Dwi Nurindah Sari** \\ *Dosen Program Studi D III Kebidanan Universitas Islam Lamongan \\ ***Mahasiswa Program Studi D III Kebidanan Universitas Islam Lamongan
}

\begin{abstract}
ABSTRAK
Pengetahuan ibu post partum tentang manfaat kolostrum sangatlah penting. Kolostrum sebagai gizi terbaik bagi bayi karena komposisi zat- zat gizi di dalamnya secara optimal mampu menjamin pertumbuhan tubuh bayi. Kualitas zat gizinya juga terbaik karena mudah diserap dan dicerna oleh usus bayi. Hasil survei awal ditemukan sebagaian besar Ibu post partum tidak memberikan kolostrumnya Tujuan penelitian ini adalah untuk mengetahui hubungan pengetahuan ibu post partum tentang manfaat kolostrum dengan pemberian kolostrum pada Bayi Baru Lahir Di BPS. Aida Hartatik Amd.Keb Ds.Dlanggu, Kec.Deket Kab.Lamongan pada bulan Mei -juni 2015

Jenis penelitian adalah analitik dengan pendekatan cross sectional Jumlah Populasi pada penelitian ini populasinya adalah ibu post partum sebanyak $30 \mathrm{ibu}$ post partum. sampel $28 \mathrm{ibu}$ post partum, diambil dengan cara simple random sampling.Variabel bebasnya adalah pengetahuan ibu post partum tentang manfaat kolostrum, sedangkan variabel tergantungnya adalah pemberian kolostrum pada bayi baru lahir. Pengambilan data dengan data primer dan diolah dengan tabulasi silang.

Dari hasil penelitian didapatkan data 21 responden $(75,0 \%)$ responden yang memberikan kolostrum pada bayinya dan ibu rata-rata yang berpengetahuan baik 20 responden $(71,4 \%)$ kemudian dilakukan penghitungan nilai statistik koefsien kontingensi didapatkan $\mathrm{C}=0,609 \mathrm{C}=0.000$ nilai $\mathrm{C}$ tabel lalu dibandingkan dengan nilai $\mathrm{p}<0,05$ hasilnya Ho ditolak

Kesimpulan dari pembahasan yakni ada hubungan pengetahuan pada ibu post partum tentang manfaat kolostrum dengan pemberian kolostrum pada bayi baru lahir. Oleh karena itu ibu post partum sebaiknya memberikan ASI pertama atau kolostrum sedini mungkin pada bayinya. dan diharapkan bidan sebagai tenaga kesehatan melakukan penyuluhan secara kontinue tentang manfaat kolostrum kepada ibu post partum.
\end{abstract}

Kata Kunci : Pengetahuan, Manfaat kolostrum, Pemberian kolostrum

\section{PENDAHULUAN}

ASI (Air Susu Ibu) sebagai gizi terbaik bagi bayi karena komposisi zat- zat gizi di dalamnya secara optimal mampu menjamin pertumbuhan tubuh bayi. Kualitas zat gizinya juga terbaik karena mudah diserap dan dicerna oleh usus bayi. (Widjaja,2004). Sehingga penggunaan Air Susu Ibu (ASI) di 
Indonesia perlu ditingkatkan dan dilestarikan. Dalam "Pelestarian Penggunaan ASI", yang perlu ditingkatkan adalah pemberian asi eksklusif, yaitu pemberian ASI ( Kolostrum) segera setelah bayi lahir sampai umur 6 bulan. Berdasarkan pengamatan peneliti bahwa semakin banyak ibu di zaman sekarang ini tidak memberikan ASI eksklusif / kolostrum kepada bayinya. Dan yang mempengaruhi pola menyusui pada masyarakat salah satu diantaranya adalah aspek sosial budaya Pendidikan, Pengetahuan. Sebagaimana yang dikemukakan bahwa salah satu faktor yang mempengaruhi kesehatan masyarakat sangat tergantung pada Pengetahuan, termasuk Pengetahuan Ibu. (Rahayu,2001)

Penelitian disuatu negara berkembang yang dipublikasikan di Pediatrics 30 Maret 2006, menunjukkan bahwa bila bayi dibiarkan menyusu sendiri saat usia 30-60 menit, tidak saja akan mempermudah keberhasilan menyusui tetapi juga akan dapat menurunkan 22\% angka kematian bayi dibawah 28 hari. (Suecox, 2006).

Dari penelitian terhadap 900 ibu disekitar JABOTABEK diperoleh fakta bahwa yang dapat memberikan kolostrumnya hanya 5\%, padahal $98 \%$ ibu-ibu tersebut menyusui. Dari penelitian tersebut juga didapatkan bahwa 37,9\% dari ibu-ibu tersebut tidak pernah mendapatkan informasi khusus tentang ASI, sedangkan kurangnya informasi tentang ASI menyebabkan ibu-ibu percaya kepada mitos-mitos bahwa ASI yang keluar pertama kali itu kotor, hal ini menyebabkan adanya kebiasaan dikalangan ibu untuk membuang kolostrum (ASI yang pertama kali keluar). (Utami Roesli,2000)

Saat ini praktik menyusui masih sangat memperihatinkan di Indonesia. Menurut Survey Demografi Keluarga Indonesia (SDKI), lebih dari 95\% ibu pernah menyusui bayinya, namun yang menyusui dalam satu jam pertama cenderung menurun dari 9\% pada tahun 1997 menjadi 3,7\% pada tahun 2002. (Depkes RI, 2006)

Menurut Survey Kesehatan Daerah (2003), Angka kematian Bayi (AKB) sebesar 116 per 100.000 kelahiran hidup. Sedangkan menurut Survey Kesehatan Daerah AKB Provinsi Jawa Timur tahun 2005 sebesar 23,71 per 1.000 kelahiran hidup, terjadi kenaikan bila dibanding AKB tahun 2004 sebesar 14,23 per 1.000 kelahiran hidup. Untuk menurunkan AKB salah satunya dengan memberikan kolostrum. Kolostrum mempunyai khasiat untuk membersihkan mekonium sehingga mukosa usus bayi yang baru lahir segera bersih dan siap menerima ASI. Kolostrum mengandung protein, zat penangkal infeksi, mineral (terutama $\mathrm{K}, \mathrm{Na}$ dan $\mathrm{Cl}$ ) dan vitamin yang larut dalam lemak (A,D,E dan K). Dengan keunggulan yang dimiliki kolostrum, cukup jelas bahwa bayi yang memperoleh ASI sedini mungkin (30 menit sesudah lahir) akan terhindar dari kemungkinan terjadinya gangguan pencernaan, infeksi usus dan penyakit lainnya (Rosita, 2008). Beberapa penelitian melaporkan faktor-faktor yang mempengaruhi awal pemberian Kolostrum yaitu petugas kesehatan, psikologi ibu yaitu kepribadian dan pengalaman ibu, sosio-budaya, tata laksana rumah sakit, kesehatan ibu dan anak, pengetahuan ibu mengenai 
manfaat kolostrum, lingkungan keluarga, peraturan pemasaran pengganti ASI dan jumlah anak. (Dwi Hapsari, 2000) Faktor-faktor tersebut diteliti dalam data SDKI 1997 yang melaporkan bahwa hanya $8,3 \%$ yang disusui dalam satu jam pertama setelah lahir dari $52,7 \%$ yang disusui dalam 24 jam pertama. (Dwi Hapsari, 2000) Pada ilmu pengetahuan terkini mengenai menyusui menunjukkan bahwa sangatlah penting bagi semua bayi manusia untuk mendapatkan kolostrum dari ibunya. Dalam 48 jam pertama kehidupan bayi-bayi manusia tidak membutuhkan air susu terlalu banyak, hanya setengah sendok teh kolostrum saat pertama menyusui dan 1-2 sendok teh di hari kedua. Kolostrum melapisi saluran pencernaan bayi dan menghentikan masuknya bakteri kedalam darah yang menimbulkan infeksi pada bayi. (Suecox, 2006)

Menurunnya angka pemberian ASI dan meningkatnya pemakaian susu formula disebabkan antara lain rendahnya pengetahuan para ibu mengenai manfaat ASI dan cara menyusui yang benar, kurangnya pelayanan konseling laktasi dan dukungan dari petugas kesehatan, persepsi-persepsi sosialbudaya yang menentang pemberian ASI, kondisi yang kurang memadai bagi para ibu yang bekerja (cuti melahirkan yang terlalu singkat, tidak adanya ruang di tempat kerja untuk menyusui atau memompa ASI), dan pemasaran agresif oleh perusahaan-perusahaan formula yang tidak saja mempengaruhi para ibu, namun juga para petugas kesehatan. (Suwiyoga 2004)

Setelah di lakukan survey awal pada bulan Januari- Februari
2015 Di BPS. Aida Hartatik Amd.Keb Dlanggu, DeketLamongan terdapat 12 ibu post partum pada semua jenis persalinan dengan bayi lahir hidup. 4 orang post partum memberikan kolostrumnya pada hari pertama setelah melahirkan, dan 8 orang $(66,67 \%)$ post partum membuang kolostrumnya setelah melahirkan, kemudian memberikan ASi pada bayinya setelah hari ke tiga melahirkan.

Melihat kasus diatas maka seorang bidan harus meningkatkan pengetahuan ibu post partum dengan cara memberikan konseling pada ibu tentang bagaimana pentingnya ASI bagi bayi ( anaknya) sejak ibu hamil. Dan mengajarkan ibu untuk melakukan perawatan payudara agar ASI bisa keluar lancar dan bayinya juga bisa menerima ASI dengan baik. Dan dilakukan IMD ( Inisiasi Menyusu Dini) segera setelah lahir agar kolostrum tidak terbuang. (Kartika,2008).

Berdasarkan data diatas, maka diadakan penelitian mengenai adanya hubungan pengetahuan ibu post partum tentang manfaat kolostrum dengan pemberian kolostrum pada Bayi Baru Lahir Di BPS. Aida Hartatik Amd.Keb Ds.Dlanggu, Kec.Deket Kab.Lamongan

\section{TUJUAN}

Tujuan Umum

Untuk mengetahui hubungan pengetahuan ibu post partum tentang manfaat kolostrum dengan pemberian kolostrum pada Bayi Baru Lahir Di BPS. Aida Hartatik Amd.Keb Dlanggu, Kec. DeketLamongan 
Tujuan Khusus

a. Mengidentifikasi pengetahuan ibu post partum tentang manfaat kolostrum Di BPS. Aida Hartatik, Amd.Keb Dlanggu Deket Lamongan

b. Mengidentifikasi tentang pemberian kolostrum pada Bayi Baru Lahir Di BPS. Aida Hartatik, Amd.Keb Dlanggu Deket Lamongan.

c. Menganalisis hubungan pengetahuan ibu post partum tentang manfaat kolostrum dengan pemberian kolostrum pada Bayi Baru Lahir Di BPS. Aida Hartatik, Amd.Keb Ds. Dlanggu, Kec. Deket Kab. Lamongan

\section{PEMBAHASAN}

\section{Hasil Penelitian}

Data Umum

Karakteristik Ibu Post Partum Berdasarkan Umur

Tabel 1 Distribusi Ibu Post Partum berdasarkan umur di BPS Aida Hartatik, Amd. Keb Desa Dlanggu Kecamatan Deket Kabupaten Lamongan pada bulan Mei-Juni 2015

\begin{tabular}{|c|l|c|c|}
\hline & Umur & Frekuensi & $\%$ \\
\hline 1. & $\leq 20$ & 3 & 10,7 \\
2. & $20-30$ & 18 & 64,3 \\
3. & $30-40$ & 7 & 25,0 \\
\hline \multicolumn{2}{|c|}{ Total } & 28 & 100 \\
\hline
\end{tabular}

Dari tabel 1 di atas diketahui sebagian besar ibu post partum berumur 20-30 tahun yaitu 18 orang $(64,3 \%)$ ibu post partum dan sebagian kecil berumur $\leq 20$ tahun yaitu 3 orang $(10,7 \%)$ ibu post partum.

Karakteristik Ibu Post Partum Berdasarkan Pendidikan

Tabel 2 Distribusi Ibu Post Partum berdasarkan pendidikan di BPS Aida Hartatik, Amd.
Keb Desa Dlanggu

Kecamatan Deket

Kabupaten Lamongan pada bulan Mei-Juni 2015

\begin{tabular}{|c|l|c|c|}
\hline No. & Pendidikan & Frekuensi & $\%$ \\
\hline 1. & SD & 2 & 7,1 \\
2. & SMP & 8 & 28,6 \\
3. & SMU & 16 & 57,1 \\
4. & D III & 2 & 7,1 \\
\hline \multicolumn{2}{|c|}{ Total } & 28 & 100 \\
\hline
\end{tabular}

Dari table 2 di atas diketahui sebagian besar ibu post partum berpendidikan SMU yaitu 16 orang $(57,1 \%)$ ibu post partum dan sebagian kecil DIII dan SD yaitu 2 orang $(7,1 \%)$ ibu post partum.

\section{Karakteristik Ibu Post Partum} Berdasarkan Pekerjaan

Tabel 3 Distribusi Ibu Post Partum berdasarkan pekerjaan di BPS Aida Hartatik, Amd. Keb Desa Dlanggu Kecamatan Deket Kabupaten Lamongan pada bulan Mei-Juni 2015

\begin{tabular}{|c|l|c|c|}
\hline No. & \multicolumn{1}{|c|}{ Pekerjaan } & Frekuensi & $\%$ \\
\hline 1. & Tidak bekerja/ IRT & 14 & 50,0 \\
2. & Tani/ buruh tani & 4 & 14,3 \\
3. & Swasta & 10 & 35,7 \\
\hline \multicolumn{2}{|c|}{ Total } & 28 & 100 \\
\hline
\end{tabular}

Dari tabel 3 di atas diketahui sebagian ibu post partum sebagai Ibu Rumah Tangga ( IRT ) yaitu 14 orang $(50,0 \%)$ ibu post partum dan sebagian kecil bekerja sebagai petani yaitu 4 orang $(14,3 \%)$ ibu post partum.

\section{Data Khusus}

Karakteristik Ibu Post Partum Berdasarkan pengetahuan ibu post partum tentang manfaat kolostrum Tabel 4 Distribusi Ibu Post Partum berdasarkan pengetahuan ibu post partum tentang manfaat kolostrum di BPS 
Aida Hartatik, Amd. Keb

Desa Dlanggu Kecamatan Deket Kabupaten Lamongan pada bulan Mei-Juni 2015

\begin{tabular}{|c|l|c|c|}
\hline $\begin{array}{c}\text { N } \\
\text { o. }\end{array}$ & $\begin{array}{c}\text { Pengetahuan ibu } \\
\text { ttg Manfaat } \\
\text { kolostrum }\end{array}$ & $\begin{array}{c}\text { Frek } \\
\text { uensi }\end{array}$ & $\%$ \\
\hline 1. & Kurang & 3 & 10,7 \\
2. & Cukup & 5 & 17,9 \\
3. & Baik & 20 & 71,4 \\
\hline \multicolumn{2}{|c|}{ Total } & 28 & 100 \\
\hline
\end{tabular}

Dari tabel 4 di atas diketahui sebagian besar ibu post partum mempunyai pengetahuan ibu post partum tentang manfaat kolostrum yang baik yaitu 20 orang $(71,4 \%)$ ibu post partum dan sebagian mempunyai pengetahuan ibu post partum tentang manfaat kolostrum yang cukup yaitu 5 orang $(17,9 \%)$ ibu post partum serta sebagian mempunyai pengetahuan ibu post partum tentang manfaat kolostrum yang kurang yaitu 3 orang $(10,7 \%)$ ibu post partum.

Karakteristik Ibu Post Partum Berdasarkan pemberian kolostrum pada bayi baru lahir

Tabel 5 Distribusi Ibu Post Partum berdasarkan pemberian kolostrum pada bayi baru lahir di BPS Aida Hartatik, Amd.Keb Desa Dlanggu Kecamatan Deket Kabupaten Lamongan pada bulan Mei -Juni 2015

\begin{tabular}{|c|c|c|c|}
\hline $\begin{array}{l}\mathrm{N} \\
\mathrm{o}\end{array}$ & $\begin{array}{l}\text { Pemberian } \\
\text { kolostrum pd } \\
\text { BBL }\end{array}$ & $\begin{array}{l}\text { Freku } \\
\text { ensi }\end{array}$ & $\%$ \\
\hline 1. & Memberikan & 21 & 75 \\
\hline 2. & $\begin{array}{l}\text { Tidak } \\
\text { memberikan }\end{array}$ & 7 & 25 \\
\hline \multicolumn{2}{|r|}{ Total } & 28 & $\begin{array}{c}10 \\
0\end{array}$ \\
\hline
\end{tabular}

Dari tabel 5 di atas diketahui sebagian besar ibu post partum memberikan kolostrumnya yaitu 21 orang $(75 \%)$ ibu post partum dan sebagian kecil tidak memberikan kolostrumnya yaitu 7 orang $(25 \%)$ ibu post partum.

Hubungan pengetahuan ibu post partum tentang manfaat kolostrum dengan pemberian kolostrum pada Bayi Baru Lahir Di BPS. Aida Hartatik Amd.Keb Ds.Dlanggu, Kec.Deket Kab.Lamongan

Tabel 6 Hubungan pengetahuan ibu post partum tentang manfaat kolostrum dengan pemberian kolostrum pada Bayi Baru Lahir Di BPS. Aida Hartatik Amd.Keb Ds.Dlanggu, Kec.Deket Kab.Lamongan pada bulan Mei -juni 2015

\begin{tabular}{|c|c|c|c|c|}
\hline \multirow[b]{2}{*}{$\begin{array}{l}\mathrm{N} \\
\mathrm{o}\end{array}$} & \multirow{2}{*}{$\begin{array}{l}\text { Pengeta- } \\
\text { huan ibu } \\
\text { tentang } \\
\text { manfaat } \\
\text { kolostrum }\end{array}$} & \multicolumn{2}{|c|}{$\begin{array}{l}\text { Pemberian kolostrum } \\
\text { pada bayi baru lahir }\end{array}$} & \multirow[b]{2}{*}{ Jumlah } \\
\hline & & $\begin{array}{l}\text { Memb } \\
\text { erikan }\end{array}$ & $\begin{array}{c}\text { Tidak } \\
\text { memberikan }\end{array}$ & \\
\hline 1. & Baik & 19 & $1(5 \%)$ & 20 \\
\hline 2. & cukup & $(95 \%)$ & $3(60 \%)$ & $(100 \%)$ \\
\hline 3. & Kurang & $\begin{array}{c}2 \\
(40 \%)\end{array}$ & $3(100 \%)$ & $\begin{array}{c}5 \\
(100 \%)\end{array}$ \\
\hline & & $0(0 \%)$ & & $\begin{array}{c}3 \\
(100 \%\end{array}$ \\
\hline & Jumlah & $\begin{array}{c}7 \\
(25 \%)\end{array}$ & $21(75 \%)$ & $\begin{array}{c}28 \\
(100 \%)\end{array}$ \\
\hline
\end{tabular}

Dari tabel 6 di atas diketahui bahwa dari 28 ibu post partum yang berpengetahuan kurang 0 orang $(0 \%)$ ibu post partum seluruhnya tidak memberikan kolostrumnya.

Dari hasil statistik koefsien kontingensi (c) dengan uji SPSS versi 16.0 dengan hasil nilai $\mathrm{C}=$ $0,609 \mathrm{C}=0.000$ dimana $\mathrm{p}<0,05$ maka Ho ditolak yang berarti terdapat hubungan pengetahuan ibu post partum tentang manfaat 
kolostrum dengan pemberian kolostrum pada bayi baru lahir.

\section{Pembahasan}

\section{Pengetahuan Ibu Post Partum Tentang Manfaat Kolostrum}

Dari Tabel 4 menunjukkan bahwa dari 28 ibu post partum yang mempunyai pengetahuan ibu post partum tentang manfaat kolostrum yang baik terdapat 20 orang $(71,4 \%)$ ibu post partum dan pengetahuan ibu post partum tentang manfaat kolostrum yang cukup yaitu 5 orang $(17,9 \%)$ ibu post partum dan ibu yang mempunyai pengetahuan ibu post partum tentang manfaat kolostrum yang kurang yaitu 3 orang ( $10.7 \%$ ) ibu post partum.

Hal tersebut juga disebabkan oleh beberapa faktor antara lain umur. Dari tabel 1 hampir sebagian ibu post partum berumur 20-30 tahun yaitu 18 orang $(64,3 \%)$ ibu post partum, Pada rentang usia ini kemungkinan pengetauan dan pengalaman terhadap aplikasi seharihari terlampaui karena semakin cukup usia, tingkat kematangan akan berkembang secara optimal termasuk didalamnya. Pengetahuan serta pengalaman seseorang dalam berfikir. (Nursalam dan Siti Pariani, 2001:134).

Bila ditinjau dari pendidikan sesuai dengan tabel 2 sebagian besar dari ibu post partum berpendidikan SMA yaitu 16 orang $(57,1 \%)$ ibu post partum. Sesuai dengan pendapat Kuncoro Ningrat (1997 : 67) semakin tinggi pendidikan seseorang, semakin mudah menerima informasi sehingga semakin banyak pula pengetahuan yang dimilikinya atau sebaliknya. Hal ini juga didukung dengan teori Soekidjo Notoatmodjo (2003) bahwasannya semakin tinggi pendidikan maka pengetahuan, keterampilan dan sikap positif. Pada ilmu pengetahuan terkini mengenai menyusui menunjukkan bahwa sangatlah penting bagi semua bayi manusia untuk mendapatkan Kolostrum dari ibunya.

Pendidikan merupakan upaya yang memberikan pengetahuan sehingga terjadi perilaku positif yang meningkat. Namun demikian ada pendapat yang menyatakan bahwa tingkat pendidikan belum tentu mempengaruhi tingkat pengetahuan seseorang.

Bila ditinjau dari pekerjaan sesuai dengan tabel 5.3 sebagian dari ibu post partum tidak bekerja (IRT) yaitu 14 orang ( 50,0\%) ibu post partum . Sebagai ibu rumah tangga yang sebagian besar waktunya dirumah dapat memperoleh informasi mengenai kolostrum dari media massa, televisi, dan lain-lain. Hal ini di dukung dengan teori menurut Mubarok (2007): Pekerjaan berhubungan dengan sosial ekonomi seseorang Semakin tinggi tingkat social ekonomi seseorang akan menambah tingkat pengetahuan.

Hasil penelitian menunjukkan tingkat pengetahuan responden tentang kolostrum adalah tinggi. Hal ini dipengaruhi oleh beberapa Faktor-faktor yang mempengaruhi awal pemberian Kolostrum yaitu petugas kesehatan, psikologi ibu yaitu kepribadian dan pengalaman ibu, sosio-budaya, tata laksana rumah sakit, pendidikan, umur,pekerjaan, kesehatan ibu dan anak, pengetahuan ibu mengenai Manfaat Kolostrum, lingkungan keluarga, peraturan pemasaran pengganti ASI dan jumlah anak (Dwi Hapsari, 2000).

Pendidikan seseorang berpengaruh pada pengetahuannya, di mana semakin tinggi pendidikan seseorang, makin banyak pula 
pengetahuan yang dimiliki. Sebaliknya, pendidikan yang rendah / kurang akan menghambat perkembangan sikap seseorang terhadap nilai baru yang di perkenalkan sehingga pengetahuan juga kurang. Hal ini terbukti dari hasil penelitian yaitu bahwa tingkat pengetahuan ibu post partum tentang manfaat kolostrum berpengaruh pada pemberian kolostrum pada bayi baru lahir. Dengan tingkat pengetahuan yang rendah lebih berpotensi tidak memberikan kolostrum di bandingkan dengan tingkat pengetahuan yang lebih tinggi.

Pengetahuan atau kognitif merupakan domain yang sangat penting untuk terbentuknya tindakan seseorang (overt behavior). Sebelum orang mengadopsi perilaku baru, di dalam diri seseorang tersebut. (Rogers,1974 dalam Notoatmodjo, 2003),

\section{Pemberian Kolostrum Pada Bayi Baru Lahir}

Tabel 5 menunjukkan bahwa pemberian kolostrum pada bayi baru lahir dari 28 ibu post partum terdapat 21 orang $(75.0 \%)$ ibu post partum yang memberikan kolostrum pada bayinya. Sedangkan 7 orang $(25.0 \%)$ ibu post partum yang tidak memberikan kolostrum pada bayinya. Ditinjau dari pendidikan ibu nifas sebagian besar berpendidikan SMA sebanyak 16 orang $(57,1 \%)$ ibu post partum. Dari hasil tersebut menunjukkan secara umum responden telah memberikan kolostrum pada bayinya. Hal ini didukung dengan pengetahuan ibu post partum yang baik tentang manfaat kolostrum.

(Dwi Hapsari, 2000) ada beberapa faktor yang mempengaruhi pemberian kolostrum, antara lain: faktor sosial budaya, faktor petugas kesehatan, psikologi ibu yaitu kepribadian dan pengalaman ibu, sosio-budaya, tata laksana rumah sakit, pendidikan, umur, pekerjaan, kesehatan ibu dan anak, pengetahuan ibu mengenai Manfaat Kolostrum, lingkungan keluarga, peraturan pemasaran pengganti ASI dan jumlah anak.

\begin{tabular}{lrr}
\multicolumn{2}{c}{ Petugas } & kesehatan \\
mempunyai & peranan & dalam \\
memberikan & informasi & tentang
\end{tabular}
manfaat kolostrum, Paritas, Seorang ibu dengan bayi pertama mungkin akan mengalami masalah ketika menyusui yang sebetulnya hanya karena tidak tahu cara menyusui yang sebenarnya, serta faktor ekonomis: dengan memberikan kolostrum yang langsung kepada bayi setelah lahir, ibu tidak perlu mengeluarkan biaya sehingga akan menghemat pengeluaran.

\section{Hubungan Pengetahuan Ibu Post Partum Tentang Manfaat Kolostrum Dengan Pemberian Kolosrtum Pada Bayi Baru Lahir}

Dari tabel 6 hasil uji statistik koefisiensi kontingensi pada tabulasi silang menunjukkan bahwa Ho ditolak yang artinya terdapat hubungan pengetahuan ibu post partum tentang manfaat kolostrum dengan pemberian kolostrum pada bayi baru lahir.

Pengetahuan yang dicakup dalam domain kognitif mencakup 6 tingkatan Tahu (know) Diartikan mengingat suatu materi yang dipelajari termasuk mengingat kembali terhadap suatu yang spesifik dari suatu bahan yang dipelajari atau rangsang yan diterima, Memahami (Comprehension) Diartikan sebagai suatu kemampuan menjelaskan secara benar tentang objek yang 
diketahui dan dapat menginterpretasikan secara benar, Aplikasi (application) Diartikan sebagai suatu kemampuan untuk menggunakan materi yang dipelajari pada situasi yang nyata, Analisis (analysis) Adalah suatu kemampuan untuk menjabarkan materi atau suatu objek ke dalam komponen komponen tapi masih dalam satu organisasi tersebut dan masih berkaitan, Sintesis (Synthesis) Menunjukkan pada satu kemampuan untuk meletakkan atau menghubungkan bagian - bagian dalam satu bentuk keseluruhan yang baru, Evaluasi (Evaluation) Berkaitan dengan kemampuan untuk melakukan penilaian terhadap suatu objek. Penilaian ini berdasarkan suatu kriteria sendiri atau menggunakan kriteria-kriteria yang ada.

Menurut Jainah (2009) ibu
dengan pengetahuan tinggi
mempunyai kecenderungan untuk
memberikan kolostrum. Hal ini
menunjukkan keterkaitan antara
pengetahuan tentang kolostrum
dengan pemberiannya. Dari tabel
terlihat ibu dengan pengetahuan
kolostrum yang tinggi mempunyai
kecenderungan yang tinggi untuk
memberikan kolostrum dibandingkan
dengan ibu dengan tingkat
pengetahuan yang rendah.
Pengetahuan merupakan domain yang sangat penting untuk terbentuknya tindakan seseorang. Dan tindakan maka akan timbul suatu kesadaran (Awareness), tertarik ( interest), penilaian (evaluation), mencoba (trial), dan adaptasi (Adaption) sehingga akhirnya orang itu mampu mengaplikasikan pengetahuan yang didapat dalam kehidupan yang nyata (Notoatmodjo,2005 : 95).
Pemberian kolostrum merupakan perilaku atau tindakan ibu. Dimana tindakan ibu tersebut dipengaruhi oleh pengetahuan tentang manfaat kolostrum. bahwasanya pengetahuan adalah faktor yang sangat penting untuk terbentuknya perilaku atau tindakan untuk merubah perilaku seseorang yang disengaja. Kemudian muncul respons dalam bentuk sikap terhadap obyek yang telah diketahui dan disadari sepenuhnya, selanjutnya dari respon sikap dibentuk perilaku. Berdasarkan pengalaman dan penelitian ternyata perilaku yang didasari oleh pengetahuan akan lebih bertahan lama dari pada perilaku yang tidak didasari oleh pengetahuan.

\section{Keterbatasan}

Keterbatasan adalah kelemahan atau hambatan dalam penelitian. Dalam hal ini peneliti akan melakukan seminimal mungkin disebabkan karena hal sebagai berikut:

Instrumen Pengumpulan Data Instrumen yang digunakan yaitu kuesioner tertutup kelemahannya bersifat subjektif atau responden

Metode Penelitian

Penelitian ini menggunakan penelitian analitik korelasional dengan pendekatan Cross Sectional sehingga dimungkinkan hasilnya kurang maksimal karena hanya diobservasi sekali saja.

Waktu penelitian

Waktu penelitian sangat singkat sehingga sample yang didapatkan terbatas jumlahnya sehingga hasilnya kurang sempurna dan kurang memuaskan. 


\section{KESIMPULAN}

1. Sebagian besar ibu Post partum Di Bps, Aida Hartatik, Amd.Keb Ds. Dlanggu Kec. Deket Kabupaten Lamongan mempunyai pengetahuaan baik tentang manfaat kolostrum.

2. Sebagian besar ibu Post Partum Di Bps, Aida Hartatik, Amd. Keb Ds. Dlanggu Kec. Deket Kabupaten Lamongan memberikan kolostrumnya pada bayi baru lahir.

3. Ada hubungan pengetahuan ibu post partum tentang manfaat kolostrum dengan pemberian kolostrum pada bayi baru lahir Di Bps, Aida Hartatik, Amd. Keb Ds. Dlanggu Kec. Deket Kabupaten Lamongan

\section{Saran}

Dari kesimpulan diatas, peneliti dapat memberikan saran sebagai berikut :

1. Bagi ibu post partum. Untuk ibu post partum khususnya agar mau memberikan kolostrumnya pada hari pertama setelah melahirkan kepada bayinya sampai usia bayi 6 bualan tanpa makanan pendamping ASI ( PASI ).

2. Bagi Tenaga Kesehatan. Bagi tenaga kesehatan terutama bidan diharapkan mampu melakukan KIE tentang pentingnya kolostrum pada bayi baru lahir. sehingga dapat meningkatkan pengetahuan ibu sebagai orang tua untuk memberikan kolostrumnya pada bayinya sendiri.

3. Bagi Peneliti Selanjutnya. Hendaknya penelitian ini dapat dijadikan data awal penelitian, untuk dapat dikembangkan lebih luas dan mengambil sampel lebih banyak sehingga hasilnya lebih representatif.

\section{DAFTAR PUSTAKA}

A Aziz Alimul Hidayat. (2003). Pengantar Kebutuhan Dasar Manusia, Aplikasi dan Proses Keperawatan. Jakarta: Salemba Medika.

Azrul Azwar. (2005). Metodologi Penelitian Kedokteran dan Kesehatan Masyarakat. Yogyakarta : Pustaka Pelajar.

Christine, Henderson dan Jones, Kethlen. (2005). Buku Ajar Konsep Kebidanan. Jakarta: EGC.

Deddy Muchtadi, (1996). Gizi Untuk Bayi, ASI, Susu Formula dan Makanan Tambahan. Jakarta: Penebar Swadaya.

Friedman, Marilyn M. (1998). Perawatan Keluarga Edisi 3. Jakarta: EGC.

Handrawan Nadesul, (2005). Makanan Sehat Untuk Bayi.. Jakarta: Puspa Swara.

Krisnatuti. (2000), Dasar-dasar Ilmu Gizi, Jakarta:YBP-SP.

Michael J. Gibney, etal. (2008). Gizi Kesehatan Masyarakat. Jakarta: EGC.

Nasrul, Effendy. (1998). Dasardasar Keperawatan Mayarakat. Jakarta: EGC.

Notoatmodjo, Soekidjo. (2003), Ilmu Kesehatan Masyarakat. Cetakan pertama. Jakarta: Rineka Cipta.

Notoatmodjo, Soekidjo. (2007), Kesehatan Masyarakat. Jakarta: Rineka Cipta. 
Nursalam dan Siti Pariani (2001). Pendekatan Praktis dan Metodologi Riset Keperawatan. Jakarta: Sagung Seto.

Nursalam. (2003). Konsep dan Penerapan Metodologi Penelitian Ilmu Keperawatan. Jakarta: Salemba Medika.

Nursalam, (2008). Konsep dan Penerapan Metodologi Penelitian Ilmu Keperawatan. Jakarta: Salemba Medika.

Pudjiadi. (2000). Ilmu Gizi dan Aplikasinya. Jakarta: DPN.

RI., Depkes. (2003). Memilih makanan Seimbang. Jakarta: Depkes RI.

Saifuddin, AB, dkk. (2006). Buku Acuan Nasional Pelayanan Kesehatan Maternal dan Neonatal. Jakarta: YBP-SP.

Soekidjo, Notoatmodjo. (2005), Metodologi Penelitian Kesehatan. Cetakan ketiga Jakarta: Rineka Cipta.

Soetjiningsih, (1997). ASI : Petunjuk Untuk Tenaga Kesehatan. Jakarta: EGC.

Sudarwan, Danim. (2003). Metode Penelitian Kebidanan.. Jakarta: EGC.

Sudiharto. (2007). Asuhan Keperawatan Keluarga. Jakarta: EGC.

Suhardjo, W, (1999). Pangan Gizi dan Pertanian. Jakarta: UI Press

Suharsimi Arikunto. (2006). Prosedur Penelitian Suatu Pendekatan Praktek. Jakarta: Rineka Cipta
Supartini, Yupi. (2004). Buku Ajar Konsep Dasar Keperawatan Anak. Jakarta: EGC.

Suprajitno. (2004). Asuhan Keperawatan Keluarga. Jakarta: EGC.

Tri Rusmi Widayatun. (1999). Ilmu Perilaku. Jakarta: EGC.

Utami Roesli. (2001). Mengenal ASI Eksklusif. Jakarta: EGC

Wahit Iqbal Mubarak. 2005. Pengantar Keperawatan Komunitas. Jakarta: Sagung Seto. 